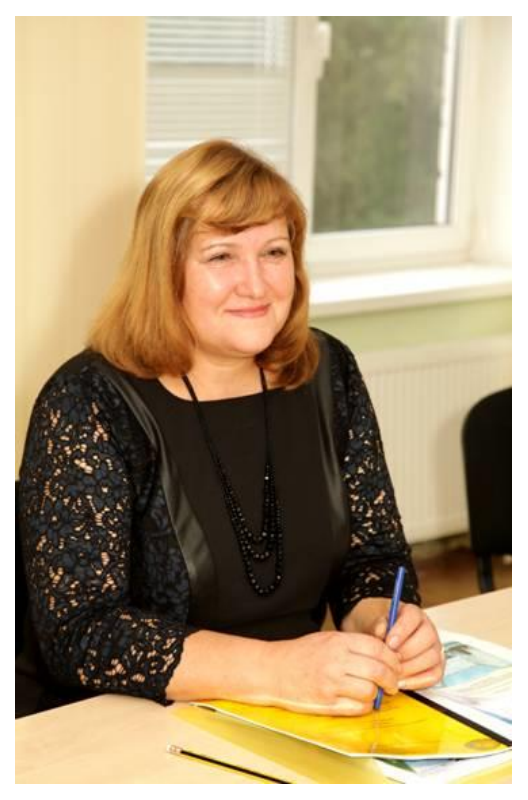

\author{
КОЦУР \\ Надія Іванівна, \\ доктор історичних наук, професор, \\ завідувач кафедри медико-біологічних \\ дисциплін і валеології ДВНЗ \\ «Переяслав-Хмельницький державний \\ педагогічний університет імені \\ Григорія Сковороди», \\ n.kozur@ukr.net \\ (м. Переяслав-Хмельницький)
}

ІНСТИТУТ ФІЗИЧНОї КУЛЬТУРИ ВУАН:

НАУКОВО-ОРГАНІЗАЦЙНІ ОСНОВИ СТАНОВЛЕННЯ

ТА РОЗВИТКУ (20-і pp. ХХ століття)

У статті на основі аналізу джерел і наукової літератури проаналізовано науково-організаційні засади становлення та розвитку Інституту фізичної культури Всеукраїнської академії наук в 20-і рр. ХХ століття. З'ясовано, що директором Інституту був відомий учений-гігієніст В.Я. Підгаєщький, під керівництвом якого проведено низку експериментальних досліджень, присвячених різноаспектним питанням фізичного виховання, гігієни, євгеніки, медичної генетики. Виділено два етапи становлення і розвитку Інституту фізичної культури ВУАН: перший - 1920-1923 рр., коли він функиіонував як самостійна установа при Науково-педагогічній комісії ВУАН; другий - 19241929 рр., період реорганізації та об'єднання із секиією охорони здоров'я дитини під назвою "Секція охорони здоров'я дитини й Інститут фізичної культури».

Встановлено, щзо впродовж означеного періоду основні завдання Інституту фізичної культури були спрямовані на вивчення проблем фізичної культури УСРР, дослідження фізичного розвитку дітей $i$ підлітків в навчальних закладах, спортклубах та встановлення фізіологічних особливостей організму дітей при дозуванні фізичного навантаження, розробку навчальних програм з фізичного виховання, розв'язання фізіологічних та гігієнічних проблем НОП (наукової організації прачі). Проаналізовано наукову спадщииу вчених Інституту фізичної культури - В.Я. Підгаєцького та М.А. Кудрииького. 
Ключові слова: Інститут фізичної культури, Всеукраїнська академія наук, фізична культура, євгеніка, медична генетика, наукова організація прачі, шкільна гігієна, В.Я. Підгаєиький, М.А. Кудриџький.

\section{INSTITUTE OF PHYSICAL EDUCATION OF AUAS: SCIENTIFIC-ORGANIZATIONAL BASIS OF FORMATION AND DEVELOPMENT (20s of the 20th century)}

In the article it is analyzed the scientific and organizational principles of the formation and development of the Institute of Physical Education of the AllUkrainian Academy of Sciences in the 20s of the 20th century on the basis of analysis of the sources and scientific literature. It was found out that the director of the Institute was a well-known scientist-hygienist V.Ya. Pidhaietskyi, under whose leadership was conducted a number of experimental studies devoted to various aspects of physical education, hygiene, eugenics, and medical genetics. Two stages of the formation and development of the Institute of Physical Education of the AUAS have been defined: the first one - 1920-1923 when it functioned as an independent institution at the Scientific and Pedagogical Commission of the AUAS; the second one - 1924-1929, the period of reorganization and association with the section of the health care of the child, entitled «Section of Child Health Care and the Institute of Physical Education».

It was established that during the mentioned period the main tasks of the Institute of Physical Education were aimed at studying of the problems of physical education of the Ukrainian SSR, studying of the physical development of children and adolescents in educational institutions, sports clubs and establishing of physiological peculiarities of the organism of children at the dosage of physical activity, developing of the curricula for physical education, solving of the physiological and hygienic problems of the SLO (Scientific Labor Organization). The scientific heritage of the scientists of the Institute of Physical Education - of V.Ya. Pidhaietskyi and M.A. Kudrytskyi-was analyzed.

Key words: Institute of Physical Education, All-Ukrainian Academy of Sciences, physical education, eugenics, medical genetics, Scientific Labor Organization, school hygiene, V.Ya. Pidhaietskyi, M.A. Kudrytskyi.

\section{ИНСТИТУТ ФИЗИЧЕСКОЙ КУЛЬТУРЫ ВУАН:}

\section{НАУЧНО-ОРГАНИЗАЦИОННЫЕ ОСНОВЫ СТАНОВЛЕНИЯ}

\section{И РАЗВИТИЯ (20-е гг. ХХ века)}

В статье на основе анализа источников и научной литературы проанализировано научно-организационные основы становления и развития Института физической культуры Всеукраинской академии наук в 20-е г2. ХХ века. Выяснено, что директором Института был известный ученыйгигиенист В.Я.Подгаеџкий, под руководством которого проведен ряд 
экспериментальных исследований, посвященных разноаспектным вопросам физического воспитания, гигиены, евгеники, медииинской генетики. Выделены два этапа становления и развития Института физической культуры ВУАН: первый - 1920-1923 г2., когда он функиионировал как самостоятельное учреждение при Научно-педагогической комиссии ВУАН; второй - 19241929 г2., период реорганизачии и объединения с секиией охраны здоровья под названием «Секция охраны здоровья и Институт физической культурыл».

Установлено, что в течение указанного периода основные задачи Института физической культуры были направлены на изучение проблем физической культуры УССР, исследования физического развития детей и подростков в учебных заведениях, спортклубах и установления физиологических особенностей организма детей при дозировке физической нагрузки, разработку учебных програми по физическому воспитанию, решение физиологических и гигиенических проблем НОТ (научной организачии труда). Проанализировано научное наследие ученых Института физической культуры - В.Я. Подгаеикого и М.А. Кудриикого.

Ключевые слова: Институт физической культуры, Всеукраинская академия наук, физическая культура, евгеника, медицинская генетика, научная организаџия труда, школьная гигиена, В.Я. Подгаеикий, М.А. Кудриикий.

У сучасних умовах погіршення стану здоров'я населення України та 3 урахуванням хвороб XXI ст. профілактичні технології повинні посісти пріоритетне місце в навчально-виховних і соціальних ініціативах держави. Адже здоров’я людини сьогодні слід розглядати не лише як найбільшу соціальну цінність, але й ключову категорію національної безпеки. ООН відносить здоров'я до показників, які визначають людський розвиток. У зв'язку 3 цим слід звернутися до позитивного досвіду щодо поліпшення здоров'я людей, нагромадженого впродовж минулого століття. Під цим кутом зору особливо актуальним $є$ вивчення історії становлення і розвитку наукових установ, інститутів, які зробили неоціненний внесок у розвиток профілактичної i соціальної медицини - розробку науково-теоретичних засад фізичного виховання, медичної генетики, євгеніки, шкільної гігієни, фізіології праці тощо.

Історичний досвід підтверджує, що надбання минулого є актуальним для сучасного, особливо під кутом зору поліпшення показників фізичного розвитку та рівня розумової і фізичної працездатності учнів і студентів з кореляцією на зміни в їх здоров’і, пов'язані зі способом життя та станом навколишнього 
середовища. Саме тому першочерговими залишаються питання здоров'я збереження учнівської і студентської молоді шляхом дотримання здорового способу життя, санітарно-гігієнічних нормативів у закладах дошкільної i шкільної освіти, установах фізичної культури, підготовка кваліфікованих педагогів-фахівців фізичної культури та лікарів, розробка науково обгрунтованих програм 3 фізичної культури 3 урахуванням вікових i індивідуальних особливостей, стану здоров'я і рівня фізичної підготовленості. Як ніколи, актуальними сьогодні у формуванні репродуктивного здоров'я та забезпеченні повноцінного генетичного фонду нації $\epsilon$ питання євгеніки i спадковості, підняті професором В.Я. Підгаєцьким ще в 20-х рр. ХХ століття під час керівництва Інститутом фізичної культури ВУАН.

Розвиток наукових досліджень у галузі гігієни фізичного виховання, шкільної гігієни, фізіології праці та євгеніки в Інституті фізичної культури ВУАН побіжно окреслено в наукових публікаціях Я.В. Ганіткевича [2; 3], В.Г. Бардова, О.П. Яворовського, А.М. Гринзовського, І.М. Захарчука [1, с. 7677], Н.І. Коцур [9, с. 539-545; 581-593], О.М. Ціборовського [21, с. 235-239]. У наукових публікаціях зазначених авторів висвітлено окремі події із життєвого шляху та творчого шляху професора В.Я. Підгаєцького та М.А. Кудрицького.

Серед сучасних історіографічних праць, присвячених окремим аспектам діяльності Інституту фізичної культури ВУАН, варто виокремити низку публікацій учених-гігієністів Ю.І. Кундієва, О. Яворовського, I.M. Трантенберга, I.М. Захарчука, О.П. Парія, в яких на основі архівних документів і великого масиву літератури подано об'єктивний матеріал щодо історії інституту та його видатних учених-гігієністів [11-12; 22-26]. У публікаціях О.М. Миздренко [13], Н.І. Коцур [9, с. 549-555] наведено огляд низки наукових праць вчених Інституту фізичної культури ВУАН. Постаті М.А. Кудрицького - ученого в галузі шкільної гігієни присвячені праці І.П. Яворовського і І.М. Захарчука [24], Я.В. Ганіткевича [2], В.Ф. Москаленка і В.В. Ляхоцького [14]. 
Таким чином, аналіз історіографії зазначеної проблеми показує відсутність в науковому просторі робіт, які б грунтовно досліджували становлення та розвиток науково-організаційних засад Інституту фізичної культури ВУАН в 20-і pp. XX ст. та дозволяє зробити висновок про необхідність і актуальність подальшої розробки наукової тематики з метою врахування досвіду минулих поколінь учених.

Мета даної розвідки полягає в тому, щоб на основі джерел та наукової літератури здійснити комплексний аналіз науково-організаційних основ становлення і розвитку Інституту фізичної культури ВУАН, окреслити внесок учених-гігієністів у розвиток досліджень у галузі гігієни фізичного виховання, євгеніки, медичної генетики, наукової організації праці, шкільної гігієни в 20-і pp. ХХ століття.

Висвітлюючи означену наукову проблему, слід звернутися до історії заснування таких наукових інституцій як Українське наукове товариство (УНТ), Українська Академія наук (УАН) та Всеукраїнська Академія наук (BУАН).

Головною науковою інституцією, спрямованою на розробку питань національної науки та культури було УНТ (засноване в 1918 р.), яке виступило 3 ініціативою про створення УАН. Становлення Української Академії наук припадає на початок 20-х pp. XX століття. Відповідно до реорганізації наукової роботи в Україні 1 червня 1921 р. УАН і УНТ були об’єднані у ВУАН, до якої перейшли всі секції та підсекції [9, с. 515].

До когорти видатних учених-лікарів, котрі зробили вагомий внесок у розвиток медичної науки як одного 3 наукових напрямів ВУАН належали Овксент Васильович Корчак-Чепурківський (1857-1947), Володимир Якович Підгаєцький (1889-1929) та Микола Антонович Кудрицький (1883-1957). Зокрема, О.В. Корчак-Чепурківський був причетним до створення Української Академії наук, входив до спеціальних комісій для вироблення ії статуту ще за часів Центральної Ради й Гетьманату, а в 1921 р. його було обрано академіком ВУАН $[15$, c. 115$]$. 
3 перших днів заснування ВУАН почала інтенсивно поповнюватися новими науковими кадрами. Це було пов'язано 3 розширенням i удосконаленням наукового супроводу соціально-економічного розвитку українського суспільства, організацією і координацією діяльності усіх наукових установ. У зв'язку з цим при ВУАН почали створюватися науково-дослідні інститути, комісії, кафедри, лабораторії, наукові товариства тощо. Зокрема, вже в 1923 р. в їі складі функціонувало 35 наукових установ, у тому числі 20 науково-дослідних кафедр [15, с. 129].

У 1920 р. при ВУАН створюється Науково-дослідний інститут фізичної культури, директором якого, за пропозицією академіка О.В. КорчакаЧепурківського, було обрано в 1921 р. професора В.Я. Підгаєцького [11, с. 50].

Аналіз джерел і літератури дав можливість виділити два етапи становлення і розвитку науково-організаційних засад Інституту фізичної культури ВУАН:

- перший етап (1920-1923рр.), коли він функціонував як самостійна установа при Науково-педагогічній комісії ВУАН;

- другий етап - 1924-1929 рр., період реорганізації під назвою «Секція охорони здоров'я дитини й Інститут фізичної культури».

На початковому етапі становлення у штаті Інституту фізичної культури ВУАН було два постійних позаштатних наукових співробітників (професори М.А. Кудрицький і С.Ю. Ярослава) та три тимчасових лікарі - П.Н. Куницький, В.М. Марич та П.Д. Марчук [11, с. 107].

Основні завдання Інституту фізичної культури були спрямовані на вивчення проблем фізичної культури УСРР, дослідження фізичного розвитку дітей i підлітків в навчальних закладах, спортклубах та встановлення фізіологічних особливостей організму дітей при дозуванні фізичного навантаження, розробку навчальних програм 3 фізичного виховання, розв'язання фізіологічних та гігієнічних проблем НОП (наукової організації праці) [12, с. 16]. Для реалізації цих завдань було створено низку наукових підрозділів: антропометричний кабінет, фізіологічна лабораторія та музей фізичної культури. Водночас у зв'язку зі слабким матеріально-технічним 
забезпеченням Інституту, ці підрозділи розробляли переважно теоретичні проблеми та здійснювали збір деяких матеріалів, оскільки кошти для проведення наукових досліджень з боку місцевої і центральної влади не виділялися.

Впродовж 1921-1923 рр., очолюваний В.Я. Підгаєцьким, Інститут фізичної культури розширює свою структуру та суттєво пожвавлює науково-дослідну роботу, поповнивши кадровий склад молодими талановитими вченими. Про його розбудову свідчать такі дані: якщо в 1920 р. структура Інституту складалася 3 трьох підрозділів, то вже в 1923 р. - 3 семи: анатомоантропометричного кабінету, лабораторії гігієни, музею фізичної культури, лабораторії біохімії, фізіологічної лабораторії, лабораторії праці, кабінету антропосоціології та євгеніки [5, с. 77]. Кожний підрозділ Інституту фізичної культури проводив науково-дослідну роботу. Широка наукова ерудиція, високий професіоналізм та обізнаність 3 новітніми досягненнями світової медичної науки В.Я. Підгаєцького сприяли дослідженню підрозділами Інституту найбільш актуальних проблем. Зокрема, анатомо-антропометричний кабінет під керівництвом його завідувача - професора М. Цішківського проводив дослідження стану опорно-рухового апарату дитини та дорослої людини; виготовляв макро- та мікропрепарати м'язів людини, мозку та інших органів. Кабінет антропосоціології та євгеніки (завідувач - доктор А. Сисак) досліджував проблеми євгеніки, медичної генетики та займався популяризацією знань серед населення про спадкові захворювання.

Лабораторія гігієни, яку очолював В.Я. Підгаєцький, досліджувала фізичний розвиток учнів у трудових школах Києва за участю доктора В. Скороходька та фізичний розвиток підлітків у спортклубах за участю доктора Л. Радкевича.

Під керівництвом доктора М.Д. Гацанюка лабораторія біохімії досліджувала вплив вітамінів на організм, проводила експерименти на тваринах та розробляла методику дослідження втоми при зміні кислотності сечі. 
Фізіологічна лабораторія, очолювана професором С.Ю.Ярославим, вивчала фізіологічні особливості розвитку дитячого організму, його відмінності від дорослого організму та досліджувала проблеми фізіології м'язової праці.

Професор В.Я. Підгаєцький також керував лабораторією праці, яка вивчала проблеми застосування методів наукової організації праці (НОП) у сільському господарстві

Наукові співробітники музею фізичної культури, під керівництвом завідувача - В. Сарнавського, розробляли навчальні програми 3 фізичного виховання для трудових шкіл, які розглядалися і затверджувалися на засіданні Науково-педагогічної комісії; організовували екскурсії до музею для учнів та вчителів місцевих шкіл і читали їм лекції [11, с. 108-109; 12, с. 16].

Отже, на першому етапі становлення Інституту фізичної культури, який став однією з вагомих наукових ланок ВУАН, під керівництвом професора В.Я. Підгаєцького розгорнулося вивчення широкого спектру актуальних питань медичної науки: гігієни фізичного виховання, євгеніки та медичної генетики, фізіології м'язової діяльності, процесів втоми, біохімії вітамінів, наукової організації праці тощо.

Організаційна робота професора В.Я. Підгаєцького в Інституті фізичної культури гармонійно поєднувалася 3 його багатогранною науковою. Про це свідчить перелік наукових праць вченого, присвячених найрізноманітнішим питанням медичної науки. Особливо вагомими були його пошуки в новій на той час галузі наукових знань - євгеніці та медичній генетиці. Спираючись на ідеї англійського біолога Ф. Гальтона - батька євгенічної вчення та на досягнення вчених інших галузей знань (санітарної гігієни, демографічної статистики, біохімії, фізіологіi), професор В.Я. Підгаєцький на основі зібраних даних теоретично обгрунтовував окремі аспекти євгеніки та медичної генетики. Аналізуючи наукові праці, опубліковані в 1922-1923 рр. слід відмітити помітний вплив на нього ідей Ф. Гальтона.

Наукова спадщина В.Я. Підгаєцького в галузі євгеніки свідчить, що його ідеалом має бути фізично здорова людина, захищена від шкідливих впливів 
урбанізованої цивілізації: одноманітної механічної праці, забрудненого довкілля, надмірного шуму, алкоголізму тощо. На думку вченого, така людина повинна бути гармонійно розвиненою як у фізичному, так і інтелектуальному плані. Євгеніка, в якій В.Я. Підгаєцький вбачав поліпшення спадкових ознак майбутніх поколінь, співпадала із завданням медичної генетики.

Характеризуючи стан розвитку українського суспільства (вузький розподіл праці, урбанізація міст, забрудненість довкілля, зниження якості їжі тощо) у статті «Роль і сучасні завдання фізичної культури» (1922), В.Я. Підгаєцький підкреслював, що ці цивілізаційні процеси деформують людину, порушують гармонійність розвитку, виснажують ії нервову систему, змінюють поведінку людини як члена суспільства. У зв'язку з цим така людина «не може зберегти ознак, що набула від предків» і є менш стійкою і захищеною біологічною істотою [16, с. 16]. До негативних факторів впливу на популяційні процеси вчений відносить війни, революції, голод, які призвели до суттєвого погіршення якісного стану населення. У статті показана динаміка смертності і народжуваності серед населення України, Росії, інших європейських країн довоєнного та післявоєнного часу. Аналізуючи статистичні дані, автор статті робить такий висновок: покоління, яке вже народилося від батьків післяреволюційного періоду і вижило «лише завдяки умовам культурного існування», а не природного відбору, або від тих, кого не брали до війська 3 причин фізичної нерозвиненості, $є$ менш цінним у біологічному розумінні, воно гірше розвинуто фізично та має низьку загальну працездатність. На його думку, найближчі покоління наших предків будуть менш витривалими фізично, більш кволими психічно, ніж попередні. Водночас, щоб поліпшити демографічні показники, в основі євгенічної політики, як вважає вчений, має лежати «піклування про фізичний розвиток, виховання фізичних здібностей, виправлення помилок у розвитку» молодого покоління [16, с. 19].

Даючи рекомендації щодо оздоровлення післяреволюційного покоління українців, В.Я. Підгаєцький пропонує здійснити низку першочергових заходів, в основі яких мають лежати такі чинники: 1) раціональне харчування людини; 
створення належних гігієнічних умов вдома, в школі та установах фізичної культури; 3) підготовка потрібної кількості кваліфікованих педагогів-фахівців фізичної культури та лікарів - науково-практичних контролерів і керівників; 4) розробка науково обгрунтованих програм з фізичної культури з урахуванням вікових особливостей, побутових та економічних умов життя. У зв’язку з цим він пропонує проводити методичну роботу 3 фізичної культури у трьох головних напрямках: а) психологічна підготовка населення щодо сприйняття ідей фізичної культури; б) наукова робота по дослідженню окремих чинників фізичної культури, вивчення iï сучасних проблем та науковому опрацюванню системи фізичної культури у відповідності 3 місцевими умовами; в) забезпечення закладів фізичної культури належним персоналом та дотриманням загальних санітарно-гігієнічних нормативів [11, с. 112]. Розроблена професором В. Я. Підгаєцьким схема щоденних заходів з фізичної культури серед широких верств населення була покладена в основу книги «Фізична культура. Вправне володіння тілом» (Київ, 1923) [18].

Таким чином, опрацьована на науковій основі євгенічна проблематика у поєднанні 3 системним підходом щодо фізичного виховання післяреволюційного покоління молоді сприяла масовому розвитку фізкультури i спорту в Радянській Україні. Підняті В.Я. Підгаєцький питання євгеніки опубліковані в таких його працях, як: «Расово-гігієнічна та соціальна роль фізичної культури» (1923), «Спадковість та євгеніка» (1924), «Свгеніка, або наука про поліпшення майбутніх поколінь» (1924).

Вагоме місце в його науковій спадщині посідала книга, видана в Харкові під назвою «Свгеніка, або наука про поліпшення майбутніх поколінь» (1924). Спираючись на відкриті чеським вченим-природознавцем Г. Менделем (1865) закономірності передавання спадкових ознак та ідеї Ф.Гальтона про можливість поліпшення успадкованих ознак предків, В.Я. Підгаєцький у цій науковій розвідці розкриває глибинну сутність вчень всесвітньо відомих дослідників, показує якого розмаху набули євгенічні знання у світі. Особливу увагу акцентує на питанні боротьби зі спадковими хворобами, яка активно 
проводиться в Англії, Франції, США та інших цивілізованих країнах. Саме тому, підкреслює В.Я. Підгаєцький, і в Україні назрів час «піклуватися поліпшенням природжених ознак у майбутніх поколінь» [17, с. 21]. Відповідно у заключній частині книги автор пропонував організувати в Україні осередки наукової роботи з проблем євгеніки - інститути, лабораторії, товариства. До завдань цих закладів має входити: 1) в галузі науки - дослідження питання спадковості шляхом анкетування, огляду, експедицій, а також проведення лабораторних досліджень; 2) у сфері практичної роботи - популяризувати серед широких мас населення знання про закони спадковості людини, про завдання євгеніки шляхом організації читання лекцій, видання книг, листівок; надання консультативної допомоги, особливо тим, хто цікавиться своєю спадковістю або хоче брати шлюб тощо. I, як зазначає автор, цю роботу в Києві розпочала секція євгеніки Інституту фізичної культури ВУАН з 1921 р. у складі професора В.Я. Підгаєцького та доктора М.С. Сисилета і вже до 1923 р. завершився перший, підготовчий та популяризаційний період іiі діяльності. Зокрема, секція євгеніки, яка розміщувалась по вулиці Кудрявській, 10 (кімната № 5) приступила до збирання анкетного матеріалу про спадковість серед мешканців Києва i серед сільського населення регіонів України та до розробки в лабораторних умовах літературних й історичних матеріалів про спадковість. Особисто професор В.Я. Підгаєцький щоденно 3 16-ої до 17-ої години консультував відвідувачів [17, с. 23].

3 метою популяризації серед населення знань про спадковість, читання лекцій, надання консультативної допомоги з різноманітних питань євгеніки при ВУАН було створено також Українське євгенічне товариство.

Отже, аналіз наукових розвідок професора В.Я. Підгаєцького свідчить, що підняті ним питання євгеніки і спадковості в 20-х рр. ХХ століття є сьогодні актуальними при розробці програм планування сім'ї, репродуктивного здоров’я, медико-генетичного консультування, спрямованих на процес відтворення здоров’я та забезпечення повноцінного генетичного фонду нації, суспільства. 
Аналіз літературних джерел свідчить, що в Інституті фізичної культури систематично проходили відкриті (прилюдні) засідання і конференції, на яких співробітники лабораторій, кабінетів і музею фізкультури доповідали про результати експериментальних досліджень, виступали з науковими доповідями [8, с. 205]. Наприклад, в 1923 р. відбулося 12 таких засідань і одна наукова конференція, матеріали якої опубліковані в збірнику наукових праць [5, с. 78].

Поширюючи ідеї фізичної культури, вчені Інституту фізичної культури підтримували тісні контакти 3 вищими навчальними закладами Києва, трудовими школами, робітничими та піонерськими клубами, військовими частинами, виступали перед їхніми колективами 3 лекціями, бесідами, друкували на сторінках їх видань результати своїх досліджень. Зокрема, в 1923 р. в друкарні Військово-редакційної ради Українського військового округу була видана брошура В.Я. Підгаєцького «Фізична культура. Вправне володіння тілом» обсягом 48 сторінок, в якій автор науково обгрунтував умови реалізації сучасної фізичної культури; зміст фізичної культури; економічне значення фізичної культури; форми фізичної культури; план фізичного удосконалення; програму фізичних вправ та дав деякі виховні поради [18].

Діяльність Інституту фізичної культури ВУАН була багатоплановою. Про це свідчить також консультативна допомога Інституту Вищій раді фізичної культури при ВУЦВК УСРР, освітнім та санітарно-просвітницьким закладам Народного комісаріату освіти Наркомату охорони здоров'я УСРР, культурноспортивним відділам і товариствам профспілок, партійним і комсомольським організаціям у розробці матеріалів методичного характеру, планів та положень щодо розвитку фізичного виховання серед усіх вікових груп населення України. Все це сприяло створенню розгалуженої мережі відділів і спортивних секцій при губернських і окружних радах фізичної культури, широкому розмаху в країні спортивний руху за фізичне оздоровлення мас $[11$, с. 116]. У закладах вищої освіти відкривались кафедри фізкультури, в школах, при робітничих клубах споруджувались спортивні майданчики, облаштовувались гімнастичні зали. У закладах системи охорони здоров'я організовувались 
постійнодіючі курси 3 підготовки спеціальних санітарних лікарів (шкільносанітарних, дитячих, робмедівських тощо), створювались науково-дослідні кабінети для визначення впливу фізичних вправ на організм людей різних вікових категорій. 3 метою контролю за станом розвитку фізичної культури в губерніях при центральному апараті Народного комісаріату охорони здоров'я УСРР був створений новий орган - Інспекторат контролю за станом розвитку фізичної культури [19].

Оцінюючи роль Інституту фізичної культури під кутом зору генерування актуальних наукових ідей та практичного їх втілення, не можна обійти увагою проблеми наукової організації праці. Їх генерували в лабораторії гігієни та праці. Наукова тематика цих лабораторій свідчить, що в них переважали дослідження, спрямовані на розв'язання гігієнічних і фізіологічних проблем наукової організації праці (НОП). Наукові працівники цих підрозділів Інституту вивчали працю різноаспектно: 3 позицій iï різновидів (інтелектуальна, фабрична, педагогічна, сільськогосподарська); впливу на організм цих видів праці; м'язового навантаження; будови тіла; залежності працездатності від тривалості робочого дня, пори року, якості їжі, стану здоров’я, фізичної витривалості тощо.

Розширюючи сферу практичного застосування результатів дослідницької діяльності, на базі лабораторії праці Інституту у серпні 1923 р. 3 ініціативи професора В.Я. Підгаєцького була заснована дослідна станція 3 наукової організації праці в сільському господарстві при Київському губвідділі профспілки «Всеробітземліс». Це була одна перших установ на теренах колишнього СРСР і Європи [22, с. 80]. Як свідчить їі програма, дослідна станція з наукової організації праці вивчала проблеми сільськогосподарської праці; розробляла питання гігієни і фізіології праці сільськогосподарських робітників у контексті їхньої безпеки; досліджувала проблеми нормалізації праці людини у зв'язку з ії технізацією; займалася питаннями реорганізації сільського господарства на засадах наукової організації праці (НОП) [11, c. 118]. 
Як завідувач Київської дослідної станції НОП в сільському господарстві і водночас директор Інституту фізичної культури ВУАН, професор В.Я. Підгаєцький підтримував тісні зв'язки 3 всесоюзними установами, організаціями і закладами. Упродовж лише 1923 р. вчений тричі їздив до Москви з експонатами, виготовленими в лабораторіях Інституту фізичної культури ВУАН, демонстрував їх на Всесоюзній сільськогосподарській виставці, за що отримав високу оцінку та Диплом вдячності [5, с. 77].

Наукові погляди на організацію праці у сільському господарстві, розроблені професором В.Я. Підгаєцьким, були визнані не лише вітчизняними, але й багатьма європейськими вченими-медиками. Його наукові пошуки дали можливість не лише розв'язувати важливі на той час народногосподарські проблеми, а й слугували поштовхом для розвитку вітчизняної медицини праці, аграрної справи і техніки безпеки в сільському господарстві. Ці факти свідчать про те, що успішний розвиток започаткованих Інститутом фізичної культури ВУАН наукових напрямків досліджень, особливо в галузі наукової організації праці в сільському господарстві та їх оприлюднення сприяли визнанню професора В.Я. Підгаєцького в широких колах наукової громадськості.

Таким чином, на першому етапі становлення Інституту фізичної культури, який став однією з вагомих наукових ланок ВУАН, під керівництвом професора В.Я. Підгаєцького розгорнулося вивчення широкого спектру актуальних питань медичної науки: гігієни фізичного виховання, євгеніки та медичної генетики, фізіології м'язової діяльності, процесів втоми, біохімії вітамінів, наукової організації праці тощо. Інститут досліджував широкий спектр проблем фізичної культури у контексті культури українського суспільства, що включали систему фізичного i санітарно-гігієнічного виховання та матеріальних засобів, необхідних для поліпшення підірваного воєнно-революційними катаклізмами i голодом 1920-1921 рр. стану здоров'я людей, зростання рівня його духовного життя як невід'ємних чинників підвищення продуктивності фабричнозаводського і сільськогосподарського виробництва, заснованого на засадах наукової організації праці. Пріоритетні напрями наукових досліджень 
Інституту фізичної культури і його керівника та втілення їх у життя поклали початок масовому розвитку фізкультури і спорту, що позитивно впливало на зміцнення здоров'я українського населення; сприяли підвищенню продуктивності виробництва, в першу чергу сільськогосподарського, заснованого на засадах наукової організації праці.

Другий етап розвиту Інституту фізичної культури ВУАН припадає на 1924-1929 рр. У цей період відбувається реорганізація Інституту. У 1924 р. його було об'єднано із секцією охорони здоров'я дітей під назвою «Секція охорони здоров'я дитини та Інститут фізичної культури», а посада «директор Інституту фізичної культури ВУАН» трансформувалася у посаду «завідувач секцією охорони здоров'я дитини та Інституту фізичної культури» [11, с. 119; 7, c. 24].

Професор В.Я. Підгаєцький, працюючи на посаді завідувача кафедрою професійної гігієни в Київському медичному інституті, за сумісництвом продовжує здійснювати керівництво Інститутом. А для посилення науководослідної роботи в 1924 р. залучає М.А. Кудрицького до роботи в очолюваний ним Інститут фізичної культури ВУАН. Водночас М.А. Кудрицький стає також позаштатним членом Науково-педагогічної комісії ВУАН та Науковопедагогічного товариства.

Слід підкреслити, що в цей період науково-педагогічна комісія під головуванням академіка О.В. Корчака-Чепурківського, якій підпорядковувався Інститут фізичної культури, діяла в складі 4-х штатних (В.Ф. Дурдуківський керівник, Б.С. Бутник-Сіверський, Г.М. Іваниця і В.Я. Підгаєцький) та 5-ти нештатних працівників [7, с. 29].

Після реорганізації Інституту фізичної культури ВУАН основні завдання і напрям наукових досліджень не зазнали суттєвих змін. Зокрема, у «Звідомленні ВУАН за 2016» [6, с. 113] відмічається, що співробітники секції охорони здоров'я дитини з Інститутом фізичної культури розробляли термінологію фізичної культури, збирали й опрацьовували матеріали про народні ігри, готувалися до участі у II Всеукраїнській науковій конференції з фізичної 
культури, а із «Звідомлення ВУАН за 2017 рік» [7] дізнаємося, що їхня тематика дещо розширилась і охоплювала такі проблеми: санітарно-гігієнічна характеристика занять фізкультурою у трудовій школі; навантаження роботою дітей у Першій трудовій школі; санітарні умови у спальнях дитячого будинку молодшого віку; електроергограма як метод вивчення втоми; санітарна характеристика сільськогосподарської праці та методи викладання й контролю знань у вищій школі. Зазначені факти є свідченням того, що Інститут фізичної культури і у складі секції охорони здоров'я дитини продовжував розробку актуальних проблем, пов'язаних зі здоров'ям людини.

Науково-дослідна робота Інституту фізичної культури цього періоду була також результативною і ефективною, про що свідчить видавнича діяльність. Зокрема, лише професор В.Я. Підгаєцький впродовж 1927-1928 рр. опублікував 14 наукових праць [11, с. 119]. Загалом 3-під пера вченого-гігієніста вийшло понад 70 наукових праць. Його праці друкувались у багатьох видавництвах, періодичних виданнях, збірниках, журналах (досить часто 3 позначкою «Інститут фізичної культури ВУАН»). Коло періодичних видань було широким i різноманітним: «Время» (Москва); «Лесовод» (Москва); «Сельскохозяйственная жизнь» (Москва); Лениниградский медицинский журнал», «Киевский медицинский журнал», «Агроном» (Київ); «Вісті ВУАН»; «Вестник физической культуры» (Харків); «Красный спорт» (Київ); «Земельник» (Харків); «Наука на Україні» (Київ); «Профилактическая медицина» (Харків); «Освіта Донбасу» (Луганськ); «Українські медичні вісті» (Київ); «Die Landarbeit» (Німеччина) тощо [9, с. 558; 11, с. 120] .

Слід відмітити вагомий внесок у розвиток науково-організаційних засад на другому етапі становлення Інституту фізичної культури ВУАН ученогогігієніста М.А. Кудрицького. Як позаштатний працівник він зосереджується на роботі в секції фізкультури Інституту під керівництвом В.Я. Підгаєцького. Секція була малочисельною, об’єднувала кілька лікарів та педагогів у галузі фізичного виховання, які досліджували проблеми розвитку української школи, розробляли термінологію фізичної культури, збирали й опрацьовували матеріал 
про народні ігри, укладаючи для цього відповідні анкети та організовуючи кадри кореспондентів на місцях [9, с. 581]. Як зазначає М.А. Кудрицький, саме в цей період остаточно визначився його науково-педагогічний шлях - шкільна гігієна з фізкультурою. Наукові інтереси вченого були зв’язані з Педкомісією, а керівниками комісії були відомі на той час учені-гігієністи - О.В. КорчакЧепурківський та В.Я. Підгаєцький. Саме вони і вплинули на подальший творчий шлях М.А. Кудрицького. На його думку, Комісія та Товариство робили велику національну справу, гуртуючи українських педагогів для вивчення проблем української школи [24].

Упродовж 1925-1926 навчального року М.А. Кудрицький проводив дослідження на базі 1-ої трудової школи імені Т.Г. Шевченка. Зокрема, під керівництвом професора В.Я. Підгаєцького вивчав проблеми фізичної працездатності учнів, методи викладання й контролю знань, складав санітарногігієнічні характеристики занять фізичною культурою, досліджував санітарні умови в спальнях дитячого будинку та школярів молодшого віку тощо. Результати цих досліджень були узагальнені в його грунтовній статті «Спроба санітарно-гігієнічної оцінки фізкультурних вправ у трудовій школі», яку він опублікував у журналі «Українські медичні вісті» $(1927$, № 1) [9, с. 582].

Особливо плідною була науково-дослідна робота М.А. Кудрицького в галузі шкільної гігієни. Він один із перших вітчизняних учених-гігієністів дослідив такі проблеми шкільної гігієни, як відповідність хронологічного віку київських школярів стану їх фізичного і психічного розвитку, а також впливу на психофізіологічний розвиток дітей занять фізичною культурою, передбачених шкільною навчальною програмою. На думку вченого, кінцева мета лікарсько-педагогічного контролю в школі полягала в обгрунтуванні оптимальної відповідності характеру (змісту) та обсягу занять фізичною культурою учнями школи до стану їх психічного та фізичного розвитку. Встановлення такої відповідальності зумовлювалась тим, що поділ на групи (навчальні класи) базувався, як правило, на хронологічному віці, а не на фізичному розвитку дитини. 
Дослідження М.А. Кудрицького були присвячені також вивченню гігієнічного аспекту впливу фізичної культури на організм дитини як такий, що спрямований на поліпшення функції як організму в цілому, так і окремих його органів і систем. Гігієнічна оцінка впливу фізичної культури на організм дітей оцінювалася вченим за інтенсивністю вправ (витратою сили за певний час), тривалістю впливу (ходьба, біг, ігри тощо), чергуванням періодів роботи i відпочинку. Оцінка сили під час м'язової роботи на заняттях з фізичної культури визначались на підставі таких показників діяльності серця і органів дихання, як частота серцевих скорочень (пульс), величина кров'яного тиску, час повернення серця до нормальної функції після фізичних вправ (функціональна проба серця), частота дихання та місткість легень.

Проводячи експеримент 3 вивчення фізіологічного впливу занять фізичною культурою на організм дітей та їх працездатність на базі 1-ої Київської трудової школи імені Т.Г. Шевченка навесні 1926 р., М.А. Кудрицький поставив наступні завдання: по-перше, провести аналіз стану фізичного розвитку дітей обстежуваної школи у порівнянні $з$ попередніми роками - 1924-1925 pр., а також дітьми інших київських та харківських шкіл; по-друге, дослідити інтенсивність впливу занять фізичною культурою шляхом застосування методу детального хронометражу, характеру і тривалості окремих видів фізичної діяльності, реєстрації частоти пульсу під час навантаження i часу його повернення до вихідного рівня, спірометрії (визначення місткості легень); по-третє, оцінити гігієнічні умови в приміщеннях, де проводилися заняття 3 фізичної культури школярів, за показниками мікроклімату (температура, вологість і швидкість руху повітря) та вмісту пилу в повітрі $[9$, c. 584] .

У процесі дослідження М.А. Кудрицьким було застосовано низку методик для визначення паспортного («фізіологічного») віку та фізичного («біологічного») розвитку школярів. Одержані ним результати дослідження показали, що за показником біологічного віку значна частина дітей у 1-ій трудовій Київській школі не відповідала їхньому паспортному віку. 
Результати проведених експериментальних досліджень М.А. Кудрицький узагальнив у таких висновках: 1) з фізіолого-гігієнічної точки зору побудову діаграм занять фізичної культури (на підставі детального хронометражу), необхідно здійснювати з урахуванням як тривалості вправ, так і напруженості окремих фізичних вправ; 2) для кожної вікової групи слід розробити нормативи щодо інтенсивності окремих форм фізичної культури з урахуванням рівня їх фізичного розвитку; 3) критерієм поділу дітей на групи для занять фізкультурою мають бути показники біологічного віку, але для кожної місцевості необхідно розробити свої нормативи фізичного розвитку (зросту та ваги тіла дітей) різного паспортного віку; 4) при проведенні занять з фізичної культури слід ураховувати такі гігієнічні параметри повітря - температуру, вологість, швидкість руху, для чого в кожній школі слід застосовувати кататермометрію [10, с. 86].

Наукові пошуки М.А. Кудрицького в галузі фізичного виховання й шкільної гігієни сприяли визнанню його серед наукової медичної громадськості України. У зв'язку з цим вченого запрошують на конференції, присвячені проблемам шкільної гігієни та фізичної культури. Зокрема, в 1927 р. він виступив 3 доповіддю на Всеукраїнській нараді з питань фізичної культури в Харкові [2, с. 78].

Особливо вагоме практичне значення мала книга М.А. Кудрицького «Здорове й хворе людське тіло» (1927) обсягом 219 с, яка була рекомендована науково-методичним комітетом Наркому освіти УССР по секції соціального виховання як посібник для установ Соцвиху та призначалася для учнів старших класів тогочасних загальноосвітніх шкіл, профтехнікумів та шкіл. Сама назва книги свідчила про те, що в ній автор намагався поєднати в школярів знання 3 анатомії, фізіології та гігієни - науки про закономірності впливу на здоров'я людини фізичних, хімічних, біологічних та психофізіологічних факторів довкілля, а також внутрішніх чинників з метою запобігання шкідливої дії та використання ії позитивних властивостей. Такий підхід дозволяв сформувати в учнів уявлення про єдність людини і природи, з'ясувати, як виникають i 
формуються захворювання, спричинені патогенним впливом шкідливих i небезпечних чинників навколишнього і внутрішнього середовища. Водночас головна увага у посібнику акцентувалася автором не на хворобах, а на способах збереження здоров'я людини. Підсумкова глава цієї книги присвячена фізіологічним особливостям праці людини, в якій автор чітко показує, що праця, яка відбувається в шкідливих умовах, негативно впливає на здоров'я людини та вперше наводить тогочасні статистичні дані щодо смертності на 1000 населення серед робітників та інших прошарків суспільства. Чільне місце автор посібника приділив питанню поліпшення умов праці як шляхом іiі раціоналізації та чергування 3 відпочинком, так і усуненням шкідливих i небезпечних чинників різного походження, які формують виробниче середовище. До всіх розділів посібника «Здорове й хворе людське тіло» автор помістив практикум та гігієнічні рекомендації [9, с. 591].

На основі доступно викладеного матеріалу, проілюстрованого 92 малюнками, посібник «Здорове й хворе людське тіло» формував у читача чітке уявлення про будову людського тіла, функції окремих органів і фізіологічних систем, причини і механізми формування окремих захворювань під впливом внутрішніх, а також зовнішніх чинників (нераціональне харчування, вживання алкоголю, неправильна постава тіла під час навчання чи інших видів праці, недостатнє освітлення, надмірний високий вміст пилу в повітрі, шум тощо) [24, с. 96].

Оцінюючи із сучасних позицій теоретичне та практичне значення навчального посібника М.А. Кудрицького «Здорове й хворе людське тіло», слід відмітити, що він став першою спробою створення вітчизняного підручника 3 профільної гігієнічної дисципліни «Гігієна дітей і підлітків», яка виокремилася в самостійну навчальну дисципліну дещо пізніше - на початку 30-х рр. років ХХ століття.

Отже, аналіз наукової спадщини М.А. Кудрицького - позаштатного співробітника ВУАН засвідчує, що він під керівництвом свого вчителя, видатного українського вченого-гігієніста В.Я. Підгаєцького досяг значних 
успіхів як у своїй науково-дослідній роботі, так і педагогічній діяльності. М.А. Кудрицький наприкінці 20-х років ХХ ст. заклав основи розвитку нового наукового напряму гігієнічних знань - шкільної гігієни. Саме тому, враховуючи негативні зрушення в стані здоров’я та фізичного розвитку сучасних школярів, підняті М.А. Кудрицьким питання гігієни фізичного виховання та навчально-виховного процесу, актуальні і сьогодні.

У 1929 р. Інститут фізичної культури як структурна одиниця ВУАН припинив своє існування. Політичні події кінця 20-х - початку 30-х років ХХ ст., що розгорнулися в Україні, порушили стабільне життя ВУАН. Внаслідок сфабрикованої ДПУ так званої справи «Спілки визволення України (СВУ)» частина вчених академії, у тому числі й вчені-лікарі медичної секції ВУАН (Барбар А., Кудрицький М., Підгаєцький В., Удовенко В. та інші) були репресовані. Окремі підрозділи медичної секції були ліквідовані або перепрофільовані на іншу наукову тематику [20; 11, с. 120].

Таким чином, Інститут фізичної культури ВУАН, очолюваний професором В.Я. Підгаєцьким, у своєму становленні і розвитку пройшов два етапи. На першому етапі (1920-1923 рр.) він функціонував як самостійна установа при Науково-педагогічній комісії ВУАН, на другому - в 1924 - 1929 рр. його об’єднано із секцією охорони здоров’я дитини під назвою «Секція охорони здоров’я дитини й Інститут фізичної культури». Наукові пошуки Інституту фізичної культури були спрямовані на вивчення проблем фізичної культури УСРР, євгеніки та медичної генетики, шкільної гігієни, дослідження фізичного розвитку дітей і підлітків в навчальних закладах, спортклубах та фізіологічної реакції організму школярів на дозоване фізичне навантаження, розробку навчальних програм з фізичного виховання, розв'язання фізіологічних та гігієнічних проблем НОП (наукової організації праці) тощо.

\section{Список використаних джерел та літератури}

1. Бардов В. Г., Яворовський О. П., Гринзовський А. М. Володимир Якович Підгаєцький - засновник першої в Україні кафедри професійної гігієни. Довкілля та здоров'я. 2002. № 2. С. 76-78. 
2. Ганіткевич Я. В. Микола Кудрицький - український науковець-гігієніст і педагог. Українські лікарі - вчені першої половини ХХ століття та їхні наукові школи : біогр. нариси та бібліографія. Львів, 2002. С. 77-81.

3. Ганіткевич Я. В. Перші українські науково-медичні школи. Народне здоров'я. Львів, 2000. № 3-4.

4. Додаткові свідчення В. Підгаєцького 27 грудня 1929 р. Остання адреса : розстріли соловецьких в'язнів з України у 1937 рp. : в 2 т. / [упоряд. : С. Кокін та ін.] ; Ю. Шаповал (відп. ред.) ; Служба безпеки України, Ін-т політ. і етнонац. дослідж. НАН України ; 2-ге вид., доопрац. і доп. Київ : Сфера, 2003. T. 1. C. 271.

5. Звідомлення Всеукраїнської Академії наук за 1923 рік. Київ : Друкарня УAH, 1923. С. 77-78.

6. Звідомлення Української Академії наук у Києві за 1926 рік. Київ, 1927. C. $113-114$.

7. Звідомлення Української Академії наук у Києві за 1927 рік. Київ : Друкарня ВУАН, 1928. 130 с.

8. Коротке повідомлення про діяльність Київських науково-дослідних кафедр / до 31.XII. 1924 р. Наукові записки / Київські наук.-дослідчі кафедри. Київ : Друкарня УАН, 1924. Т. 2. С. 98-208.

9. Коцур Н. І. Становлення і розвиток гігієнічної науки в Україні : шлях крізь епохи і соціальні потрясіння (друга половина XIX - 20-і pp. XX століття) : монографія. Корсунь-Шевченківський, 2011. 726 с.

10. Кудрицький М. А. Спроба санітарно-гігієнічної оцінки фізкультурних вправ у трудовій школі (3 Інституту Фізичної Культури УАН. Дир. проф. В. Підгаєцький). Українські медичні вісті. 1927. № 1. С. 86.

11. Кундієв Ю. І., Яворовський О. П., Трахтенберг І. М., Сахарчук I. М. Володимир Підгаєцький : повернення із забуття. 1889-1937. Житомир : Полісся, 2008. 324 с.

12. Кундієв Ю. І., Яворовський О. П., Парій В. Д., Сахарчук І. М. Доля родини репресованого вченого-гігієніста. Житомир : Полісся, 2009. 110 с.

13. Миздренко О. М. Вчення про наукову організацію праці в сільському господарстві професора В. Я. Підгаєцького (20-ті рр. XX ст.). Наукові записки з української історії. Переяслав-Хмельницький, 2012. Вип. 28. С. 365-371.

14.Москаленко В. Ф., Ляхоцький В. П. Таврований епохою. Науковий вісник Наиіонального медичного університету імені О. О. Богомольия. 2006. № 1. C. 178-179.

15. Онопрієнко В., Реєнт О., Щербань Т. Українське наукове товариство : 1907-1921 роки. Київ, 1998. С. 114-116, 129.

16. Підгаєцький В. Я. Роль і сучасні завдання фізичної культури. Киевский медииинский журнал. 1922. № 6. С. 15-22.

17. Підгаєцький В. Я. Спадковість та євгеніка. Додаток до журн. «Шлях освіти». 1923. № 11-12. С. 1-23.

18. Підгаєцький В. Фізична культура. Вправне володіння тілом. Київ : Друкарня Військ.-ред. ради Київської військ. округи, 1923. 48 с.

19. Підгаєцький В. Я. Фабрична гігієна. Харків : Друкар, 1923. 6 с. 
20. Підсумки шефства ВУАН над Сталінщиною. Вісті ВУАН. 1930. № 6. C. 35 .

21. Ціборовський О. М. На варті здоров'я : історія становлення соціальної медицини і охорони громадського здоров'я в Україні : монографія. Київ : Факт, $2010.430 \mathrm{c}$.

22. Яворовський О. П. Науковий спадок професора В. Я. Підгаєцького і його вчення про наукову організацію праці в сільському господарстві України. Український журнал з проблем медицини праці. 2006. № 4. С. 78-86.

23. Яворовський О. П. Володимир Якович Підгаєцький - засновник першої кафедри професійної гігієни. Украӥнський журнал з проблем медицини nраųi. 2006. № 1. С. 83-90.

24. Яворовський О. П., Сахарчук I. М. Микола Кудрицький. Лікар. Педагогог. Вчений. Черкаси : ТОВ «Маклаут», 2009.156 с.

25. Яворовський О. П., Сахарчук І. М. Повернення із забуття наукової спадщини В. Я. Підгаєцького : результати пошуків, проблеми, перспективи. Науковий вісник Національного медичного університету імені О. О. Богомольия. 2006. № 4. С. 256-270.

26. Яворовський О. П. Професор В. Я. Підгаєцький - засновник кафедри професійної гігієни та навчальних курсів із шкільної гігієни фізичної культури в Київському медичному інституті. Науковий вісник Національного медичного університету імені О. О. Богомольия. 2006. № 3. С. 234-240.

\section{References}

1. Bardov, V. G., Yavorovskyj, O. P. and Grynzovskyj, A. M. (2002). Volodymyr Yakovych Pidgayeczkyj - zasnovnyk pershoyi $v$ Ukrayini kafedry profesijnoyi gigiyeny [Volodymyr Yakovlevich Pidhaietskyi is the founder of the first Ukrainian department of occupational hygiene.]. Dovkillya ta zdorovya [Environment and health]. 2. 76-78. [in Ukrainian].

2. Hanitkevych, Ya. V. (2002). Mykola Kudrytskyi - ukrainskyi naukovetshihiienist $i$ pedahoh [Mykola Kudrytskyi is Ukrainian scientist-hygienist and pedagogue]. Ukrainski likari - vcheni pershoi polovyny XX stolittia ta yikhni naukovi shkoly : biohr. narysy ta bibliohrafiia [Ukrainian doctors - scientists of the first half of the XX century and their scientific schools: biogr. essays and bibliography]. Lviv. 77-81. [in Ukrainian].

3. Hanitkevych, Ya. V. (2000). Pershi ukrainski naukovo-medychni shkoly [The first Ukrainian scientific medical schools]. Narodne zdorovia [Folk health]. Lviv. 3-4. [in Ukrainian].

4. (2003). Dodatkovi svidchennia V. Pidhaietskoho 27 hrudnia 1929 r. [Additional evidence of V. Pidhaietskyi December 27, 1929]. Ostannia adresa: rozstrily solovetskykh viazniv z Ukrainy u $1937 \mathrm{rr}$. : $v 2 \mathrm{t}$. [Last address : Shooting of Solovetsky prisoners from Ukraine in 1937: 2 t.] / [uporiad. : S. Kokin ta in.]; Yu. Shapoval (vidp. red.) ; Sluzhba bezpeky Ukrainy, In-t polit. i etnonats. doslidzh. HAH Ukrainy. 2-he vyd., dooprats. i dop. Kyiv : Sfera, 1. 271. [in Ukrainian]. 
5. (1923). Zvidomlennia Vseukrainskoi Akademii nauk za 1923 rik [Report of the All-Ukrainian Academy of Sciences for 1923]. Kyiv : Drukarnia UAN. 77-78. [in Ukrainian].

6. (1927). Zvidomlennia Ukrainskoi Akademii nauk u Kyievi za 1926 rik [Announcement of the Ukrainian Academy of Sciences in Kyiv for 1926]. Kyiv. 113-114. [in Ukrainian].

7. (1928). Zvidomlennia Ukrainskoi Akademii nauk u Kyievi za 1927 rik [Announcement of the Ukrainian Academy of Sciences in Kyiv for 1927]. Kyiv : Drukarnia UAN, 130. [in Ukrainian].

8. (1924). Korotke povidomlennia pro diialnist Kyivskykh naukovo-doslidnykh $k a f e d r /$ do 31.XII. 1924 r. [A brief report on the activities of the Kiev scientific research departments / until 31.XII. 1924]. Naukovi zapysky / Kyivski nauk.-doslidchi kafedry [Scientific notes / Kyiv sciences-research departments.]. Kyiv: Drukarnia UAN, 2. 98-208. [in Ukrainian].

9. Kotsur, N. I. (2011). Stanovlennia i rozvytok hihiienichnoi nauky v Ukraini : shliakh kriz epokhy $i$ sotsialni potriasinnia (druha polovyna XIX - 20-i rr. $X X$ stolittia) : monohrafiia [Formation and development of hygienic science in Ukraine: the way through the ages and social upheavals (second half of the nineteenth and twentieth centuries of the twentieth century): a monograph]. KorsunShevchenkivskyi. 726. [in Ukrainian].

10. Kudrytskyi, M. A. (1927). Sproba sanitarno-hihiienichnoi otsinky fizkulturnykh vprav u trudovii shkoli (3 Instytutu Fizychnoi Kultury UAN. Dyr. prof. V. Pidhaietskyi) [Attempt of sanitary-hygienic assessment of physical exercises in a labor school (3 Institute of Physical Culture of the UAN, director Prof. V. Podgaitsey)]. Ukrainski medychni visti [Ukrainian medical news]. 1. 86. [in Ukrainian].

11. Kundiiev, Yu. I., Yavorovskyi, O. P., Trakhtenberh, I. M. and Sakharchuk, I. M. (2008). Volodymyr Pidhaietskyi : povernennia iz zabuttia. 18891937. [Volodymyr Pidhaytsky: A Return From oblivion. 1889-1937]. Zhytomyr : Polissia. 324. [in Ukrainian].

12. Kundiiev, Yu. I., Yavorovskyi, O. P., Parii, V. D. and Sakharchuk, I. M. (2009). Dolia rodyny represovanoho vchenoho-hihiienista [The fate of the family of the repressed scientist-hygienist]. Zhytomyr : Polissia, 110. [in Ukrainian].

13. Myzdrenko, O. M. (2012). Vchennia pro naukovu orhanizatsiiu pratsi $v$ silskomu hospodarstvi profesora V. Ya. Pidhaietskoho (20-ti rr. XX st.). [The doctrine of the scientific organization of labor in agriculture by professor V. Ya. Pidjaytsky (20-ies of the twentieth century)]. Naukovi zapysky z ukrainskoi istorii. PereiaslavKhmelnytskyi [Scientific notes on Ukrainian history]. 28. 365-371. [in Ukrainian].

14. Moskalenko, V. F. and Liakhotskyi, V. P. (2006). Tavrovanyi epokhoiu [Tavrovany epoch]. Naukovyi visnyk Natsionalnoho medychnoho universytetu imeni O. O. Bohomoltsia [Scientific Bulletin of the National Medical University named after O. Bohomolets]. 1. 178-179. [in Ukrainian].

15. Onopriienko, V., Reient, O. and Shcherban, T. (1998). Ukrainske naukove tovarystvo : 1907-1921 roky. [Ukrainian Scientific Society : 1907-1921 years]. Kyiv. 114-116, 129. [in Ukrainian]. 
16. Pidhaietskyi, V. Ya. (1922). Rol i suchasni zavdannia fizychnoi kultury [The role and modern tasks of physical culture]. Kyevskyi medytsynskyi zhurnal [Kiev Medical Journal]. 6. 15-22. [in Ukrainian].

17. Pidhaietskyi, V. Ya. (1923). Spadkovist ta yevhenika [Heredity and eugenics]. Dodatok do zhurn. "Shliakh osvity» [Appendix to the journal «Path of Education»]. 11-12. 1-23. [in Ukrainian].

18. Pidhaietskyi, V. (1923). Fizychna kultura. Vpravne volodinnia tilom [Physical Education. Exquisite possession of the body.]. Kyiv : Drukarnia Viisk.-red. rady Kyivskoi viisk. Okruhy. 1923. 48. [in Ukrainian].

19. Pidhaietskyi, V. Ya. (1923). Fabrychna hihiiena [Factory hygiene]. Kharkov : Drukar, 6. [in Ukrainian].

20. (1930). Pidsumky shefstva VUAN nad Stalinshchynoiu [Results of VUAN's patronage over Stalin's region]. Visti VUAN [Visiting WUAN]. 6. 35. [in Ukrainian].

21. Tsiborovskyi, O. M. (2010). Na varti zdorovia: istoriia stanovlennia sotsialnoi medytsyny $i$ okhorony hromadskoho zdorovia $v$ Ukraini : monohrafiia [On health care : the history of becoming a social medicine and public health protection in Ukraine : a monograph]. Kyiv : Fakt, 430. [in Ukrainian].

22. Yavorovskyi, O. P. (2006). Naukovyi spadok profesora V. Ya. Pidhaietskoho $i$ yoho vchennia pro naukovu orhanizatsiiu pratsi v silskomu hospodarstvi Ukrainy [The scientific heritage of Professor V. Ya. Pidhaietskyi and his teaching on the scientific organization of labor in agriculture in Ukraine]. Ukrainskyi zhurnal $z$ problem medytsyny pratsi [Ukrainian Journal of Medical Problems]. 4. 78-86. [in Ukrainian].

23. Yavorovskyi, O. P. (2006). Volodymyr Yakovych Pidhaietskyi - zasnovnyk pershoi kafedry profesiinoi hihiieny [Volodymyr Yakovlevich Pidhaietskyi is the founder of the first department of professional hygiene]. Ukrainskyi zhurnal $z$ problem medytsyny pratsi [Ukrainian Journal of Medical Problems]. 1. 83-90. [in Ukrainian].

24. Yavorovskyi, O. P., Sakharchuk, I. M. (2009). Mykola Kudrytskyi. Likar. Pedahohoh. Vchenyi [Mykola Kudrytskyi. Doctor. A pedagogue Scientist.]. Cherkasy : TOV «Maklaut», 156. [in Ukrainian].

25. Yavorovskyi, O. P. and Sakharchuk, I. M. (2006). Povernennia iz zabuttia naukovoi spadshchyny V. Ya.Pidhaietskoho: rezultaty poshukiv, problemy, perspektyvy [Return from oblivion of the scientific heritage V. Ya. Pidhaietskyi: results of searches, problems, perspectives]. Naukovyi visnyk Natsionalnoho medychnoho universytetu imeni O. O. Bohomoltsia [Scientific Bulletin of the National Medical University named after O. Bohomolets]. 4. 256-270. [in Ukrainian].

26. Yavorovskyi, O. P. (2006). Profesor V. Ya. Pidhaietskyi - zasnovnyk kafedry profesiinoi hihiieny ta navchalnykh kursiv iz shkilnoi hihiieny fizychnoi kultury v Kyivskomu medychnomu instytuti [Professor V. Ya. Pidhaietskyi is the founder of the Department of Occupational Hygiene and Training Courses on School Hygiene of Physical Culture at the Kiev Medical Institute]. Naukovyi visnyk Natsionalnoho medychnoho universytetu imeni O. O. Bohomoltsia [Scientific 
Bulletin of the National Medical University named after O. Bohomolets]. 3. 234-240. [in Ukrainian].

\section{Рецензент:}

Бородай I.C., д.і.н., проф. 